\title{
ПРИНЦИПИ ПІДГОТОВКИ СТУДЕНТІВ АГРАРНИХ СПЕЦІАЛЬНОСТЕЙ ДО ПРОФЕСІЙНОГО СПІЛКУВАННЯ В ІНШОМОВНОМУ СЕРЕДОВИЩІ
}

Ніколаєнко Ю. О. Принципи підготовки студентів аграрних спеціальностей до професійного спілкування в іншомовному середовищі.

У статті проаналізовано принципи підготовки студентів аграрних спеціальностей до професійного спілкування в іншомовному середовищі. Визначено специфіку кожного принципу в системі іншомовної підготовки майбутніх аграріїв.

Ключові слова: принципи підготовки, професійне спілкування, студенти аграрних спеціальностей, іншомовне середовище.

Николаенко Ю. А. Принципы подготовки студентов $\quad$ аграрных $\quad$ специальностей $\quad$ к профессиональному общению в иноязычной среде.

В статье проанализированы принципы подготовки студентов аграрных специальностей к профессиональному общению в иноязычной среде. Определена специфика каждого принципа в системе иноязычной подготовки будущих аграриев.

Ключевые слова: принципы подготовки, профессиональное общение, студенты аграрных специальностей.

Nikolayenko Y. The principles of training students of agrarian specialities for professional communication in foreign linguistic environment.

The article deals with the analyses of the principles of training students of agrarian specialities for professional communication in foreign linguistic environment. The specific character of each principle in the foreign language training of future agrarian specialists has been determined.

Key words: the principles of training, the students of agrarian specialities, professional communication, a foreign linguistic environment.

У сучасному світі володіння іноземною мовою $є$ необхідним у будь-якій професійній діяльності, адже іншомовна компетентність підвищує професіоналізм, мобільність та конкурентоспроможність фахівців на ринку праці. Саме тому проблеми підготовки майбутніх фахівців до іншомовного спілкування стають предметом численних наукових досліджень.

Окремі аспекти комунікативної підготовки студентів агарних ВНЗ розкрито в працях С. Амеліної, Л. Барановської, В. Кручек, І. Ляшенко, В. Михайлюк. Аналіз цих досліджень доводить, що комунікативна компетентність $є$ обов'язковим складником професійної компетентності фахівців аграрного профілю. Проте недостатньо вивченими є проблеми іншомовної підготовки майбутніх аграріїв. Зокрема, в умовах розширення міжнародного співробітництва нашої держави у сфері сільського господарства постає необхідність розроблення цілісної системи навчання майбутніх аграріїв професійного спілкування, що сприятиме їхній ефективній взаємодії із зарубіжними колегами в іншомовному середовищі. Розроблення такої системи вимагає комплексного аналізу всіх їі компонентів, одним із яких $\epsilon$ принципи навчання.

Підготовка студентів аграрних спеціальностей до професійного спілкування в іншомовному середовищі розглядається нами як важливий складник їхньої фахової підготовки. Це спеціально організований та педагогічно керований процес, який спрямований на формування в майбутніх аграріїв готовності ефективно взаємодіяти у професійній сфері нерідного лінгвокультурного соціуму, зокрема, під час проходження практики чи навчання за кордоном. Нами розроблено модель підготовки студентів аграрних спеціальностей до професійного спілкування в іншомовному середовищі, яка складається із комплексу таких взаємопов'язаних і взаємозалежних компонентів, як цільовий (підхід і мета підготовки), змістовий (принципи і зміст підготовки), 
організаційно-методичний (технологія підготовки) i оцінювально-результативний (результат підготовки). У цій статті ми детально розглянемо один із компонентів нашої моделі, а саме принципи професійної іншомовної підготовки.

Meта cmammi - визначити та проаналізувати принципи підготовки студентів аграрних спеціальностей до професійного спілкування в іншомовному середовищі.

У сучасній методиці відсутня єдина універсальна класифікація принципів навчання іноземних мов. Найчастіше розрізняють загальні принципи, які не залежать від умов навчання і мають досить універсальний характер, та власне методичні, що відображають специфіку іноземної мови як навчальної дисципліни [5, с. 156]. Більшість авторів визначають принципи комунікативності, функціональності, ситуативно-тематичної організації навчального матеріалу, урахування рідної мови, комплексності, інтенсивності, урахування майбутньої спеціальності студентів тощо. Однак цей перелік не $\epsilon$ систематизованим.

На нашу думку, обгрунтування принципів підготовки майбутніх аграріїв до професійного іншомовного спілкування є важливим етапом у розробленні моделі такої підготовки. Ми цілком погоджуємося із твердженням Є. Пассова про те, що «принципи є фундаментом будівлі, назва якої «процес навчання». Жодна проблема - відбір і організація матеріалу, вибір вправ та побудова їх системи, вибір прийомів роботи тощо не може бути вирішена без чіткого уявлення про принципи навчання» [2, с. 111].

Оскільки провідним у навчанні іноземних мов є комунікативний підхід (К. Брамфіт, К. Джонсон, І. Зимня, Г. Колшанський, У. Літтелвуд, С. Мельник, Ю. Пассов, В. Скалкін, Х. Уідоусан), у підготовці до іншомовного спілкуваннями спираємося на класифікацію Ю. Пассова, який обгрунтував принципи навчання спілкування. Це принцип мовленнєворозумової активності, індивідуалізації, функціональності, ситуативності і новизни [2]. Усі вони можуть бути застосовані у процесі підготовки студентів аграрних спеціальностей до професійного спілкування в іншомовному середовищі.

Принции мовленнєворозумової активності передбачає, що студенти на заняттях не просто сприймають певну інформацію, яка подається викладачем, а $є$ активними учасниками процесу професійного іншомовного спілкування, що відбувається в аудиторії. Для цього необхідно не просто ставити завдання прочитати текст, відповісти на питання чи скласти діалог. Будь-яка навчальна діяльність студентів має бути організована таким чином, щоб у них виникла необхідність здійснити певний «мовленнєвий вчинок», вирішити «мовленнєворозумове завдання» (Ю. Пассов). Лише за таких умов процес спілкування в аудиторії перестане бути просто формальним виконанням інструкцій викладача, а наблизиться до реальної професійної взаємодії фахівців.

Важливу роль у забезпеченні активної позиції студентів відіграє створення проблемних ситуацій. Багато авторів наголошують на тому, що проблемність має бути одним 3 головних принципів навчання іноземних мов (М. Давидова, І. Зимня, Ю. Пассов). Слушною є думка О. Тарнопольського, який вважає, що ділове спілкування завжди пов'язане 3 розв'язанням певних завдань і проблем, i, таким чином, проблемність випливає із самого змісту ділового спілкування. Тільки високопроблемне навчання ділового спілкування буде відображати реальну дійсність $[3$, с. 88]. Це цілком справедливо щодо професійного спілкування. Згідно 3 комунікативним підходом підготовка студентів до професійного спілкування повинна відбуватися як моделювання реального професійного спілкування, яке є проблемним за своєю сутністю, отже, і процес такої підготовки має носити проблемний характер. Це зумовлює принциип проблемності в підготовці студентів аграрних спеціальностей до професійного спілкування в іншомовному середовищі.

Принцип індивідуалізації дозволяє враховувати індивідуальні особливості студентів їхні здібності, уміння здійснювати навчальну i мовленнєву діяльність, особистісні характеристики. Цей принцип Ю. Пассов назвав серцевиною комунікативного навчання, одним 3 головних засобів формування мотивації [2, с. 121]. У реальних ситуаціях 
професійного спілкування його суб'єкти хоч і виступають як виконавці певних соціальних ролей, але поводять себе по-різному, і їхні індивідуальні особливості (досвід, інтереси, цінності, моральні якості тощо) впливають на всі етапи взаємодії - починаючи з усвідомлення потреб і закінчуючи вибором засобів, тактик, стратегій, стилю спілкування. Індивідуальні особливості студентів виявляються під час моделювання реального професійного іншомовного спілкування, а врахування цих особливостей допомагає викладачу краще організувати процес взаємодії та підвищити його ефективність, а отже, позитивно впливає на результат підготовки студентів аграрних спеціальностей до професійного спілкування в іншомовному середовищі.

Принции функціональності забезпечує адекватний відбір матеріалу. Студенти аграрних спеціальностей вивчають іноземну мову як засіб спілкування в нерідному мовному середовищі, тому головна увага має бути сконцентрована на мовленнєвих, а не на мовних засобах. Інформація про мову як систему повідомляється студентам лише тоді, коли це сприяє формуванню мовленнєвих умінь і навичок. Принцип функціональності зумовлений тим, що у процесі підготовки до професійного спілкування в іншомовному середовищі студенти не можуть засвоїти всю систему мовленнєвих засобів іноземної мови. Тому відбирається певний мінімум мовленнєвих засобів, засвоєння яких дозволяє студентам здійснювати професійне спілкування в іншомовному середовищі на комунікативно достатньому рівні. Цей термін був запропонований Е. Шубіним для позначення такого рівня володіння іноземною мовою, який забезпечує прийом і передачу інформації тільки за певних комунікативних умов [4]. О. Тарнопольський розуміс комунікативну достатність як допустимий максимум обмежень щодо: 1) рівня сформованості умінь і навичок мовленнєвої діяльності; 2) кола мовленнєвих завдань, які студенти повинні навчитися розв'язувати; 3) номенклатури мовленнєвих актів, які вони повинні засвоїти. «Це коло і ця номенклатура можуть вважатися комунікативнодостатніми під час навчання в немовному вищому навчальному закладі, якщо з їхньою допомогою майбутні спеціалісти зможуть задовольняти свої найбільш вірогідні і поширені потреби в іншомовному мовленнсвому спілкуванні головним чином під час виконання професійних функцій», - пише автор [3, с. 38]. Рівень комунікативної достатності допускає неідеальне володіння мовою: головне, щоб студенти розуміли основну інформацію усних і письмових текстів іноземною мовою, а їхні помилки під час створення власних усних чи письмових висловлювань не спотворювали зміст повідомлень. Отже, якщо український фахівець, потрапивши в іншомовне середовище, спілкується з іноземними партнерами на професійні теми, порушуючи певні лінгвістичні чи соціокультурні норми, але це не заважає досягненню взаєморозуміння, то можна говорити про комунікативну достатність.

Принцип ситуативності визначає пріоритетну роль ситуації в організації процесу підготовки до професійного спілкування в іншомовному середовищі. Як зазначається в рекомендаціях Ради Європи 3 мовної освіти, ситуації разом зі сферами спілкування утворюють контекст - сукупність подій або ситуаційних чинників (фізичних та інших), які можуть бути зовнішніми чи внутрішніми щодо особи і в яких відбуваються комунікативні акти $[6$, с.9]. На нашу думку, розуміння ситуації як сукупності певних умов є досить спрощеним. Тому ми повністю погоджуємося з думкою Ю. Пассова, який доводить, що в основі ситуації лежить взаємодія: «ситуація - це універсальна форма функціонування процесу спілкування, яка існує як інтегративна динамічна система соціально-статусних, рольових, діяльнісних i моральних взаємовідносин суб'єктів спілкування i яка відображається в їхній свідомості та виникає на основі взаємодії ситуативних позицій учасників спілкування» [2, с. 57]. Отже, принцип ситуативності передбачає, що у процесі підготовки студентів до професійного іншомовного спілкування усі види мовленнєвої діяльності повинні здійснюватися в контексті взаємовідносин комунікантів.

Принции новизни стосується відбору як змісту підготовки до професійного спілкування в іншомовному середовищі, так і прийомів і форм навчання. Цей принцип передбачає можливість вносити зміни та вдосконалювати процес підготовки до професійного 
спілкування, а також адаптувати його до нових соціальних вимог, що особливо важливо в умовах прискореного науково-технічного прогресу. Принцип новизни дозволяє підтримувати інтерес студентів до спілкування на високому рівні, що стимулює їхню активність та впливає на формування позитивної мотивації, спонукає викладачів до пошуку нових ефективних методів та технологій навчання і таким чином сприяє їхньому професійному самовдосконаленню.

3 огляду на те, що ми готуємо студентів до спілкування у професійній сфері, вважаємо необхідним урахування ще кількох принципів, що відображають специфіку професійної взаємодії в іншомовному середовищі. Це принцип професійної спрямованості навчальної діяльності студентів, принцип міжпредметних зв'язків іноземної мови зі спеціальними дисциплінами і принцип культурологічності.

Принщип професійної спрямованості навчальної діяльності студентів передбачає, що навчальне іншомовне спілкування студентів в аудиторії повинне імітувати реальне професійне спілкування фахівців аграрного профілю в іншомовному середовищі. Як показує практика, багато викладачів професійну спрямованість часто розуміють лише як роботу 3 текстами, що містять інформацію, пов'язану 3 майбутньою спеціальністю студентів. Таке занадто спрощене трактування $\epsilon$ хибним. Принцип професійної спрямованості означає, що всі види навчальної діяльності студентів на занятті з іноземної мови є «професійно забарвленими»: на кожному етапі заняття будь-яка робота з уміннями i навичками говоріння, аудіювання, читання і письма відбувається у змодельованих ситуаціях, які повинні відображати структуру i функції реального професійного спілкування аграріїв в іншомовному середовищі.

Із принципом професійної спрямованості навчальної діяльності студентів безпосередньо пов'язаний принциип міжпредметних зв'язків іноземної мови зі спечіальними дисциплінами. Як відомо, вивчення іноземної мови в аграрних ВНЗ випереджає вивчення спеціальних дисциплін. Отже, у процесі підготовки до професійного спілкування в іншомовному середовищі студенти аграрних спеціальностей отримують початкові знання зі сфери своєї майбутньої професійної діяльності, які вони пізніше розширюватимуть під час вивчення спеціальних дисциплін. Ми цілком погоджуємося 3 позицією Е. Комарової, що встановлення у процесі професійного спілкування зв'язків іноземної мови 3 профілюючими дисциплінами «не тільки сприяє більш глибокому і точному засвоєнню іншомовного матеріалу студентами, але й озброює їх уміннями застосовувати отримані у ВНЗ теоретичні і практичні знання в усьому їхньому комплексі в майбутній професійній діяльності» [1, с. 81].

Принцип культурологічності в підготовці до професійного спілкування в іншомовному середовищі дозволяє студентам оволодіти зразками нормативної комунікативної поведінки, які є характерними для професійної взаємодії в тих країнах, мову яких вони вивчають. Слід наголосити, що оволодіння стандартами поведінки професійного спілкування має носити практичний характер: студенти повинні не просто ознайомитися 3 ними, але й через відповідну систему вправ сформувати уміння i навички стандартизованої поведінки в іншомовному середовищі. Таким чином розвивається нормативно-рефлексивний компонент готовності до професійного спілкування в іншомовному середовищі.

Отже, можемо зробити висновок, що всі вищезгадані принципи є невід'ємним компонентом системи підготовки студентів аграрних спеціальностей до професійного спілкування в іншомовному середовищі. Необхідно наголосити, що всі вони $\epsilon$ взаємозумовленими та взаємопов'язаними і тільки за умови комплексного врахування всіх принципів іншомовна підготовка майбутніх аграріїв буде ефективною. У подальшому вважаємо перспективним розроблення теоретичних та практичних основ спецкурсу «Підготовка до проходження навчально-виробничої практики за кордоном» для студентів аграрних ВН3. 
1. Комарова Э. П. Основы обучения иноязычному профессионально ориентированному опосредованному общению в системе вузовского образования / Э. П. Комарова. - Воронеж : Издво ВГТУ, 2000. - 175 с. 2. Пассов Е. И. Основы коммуникативной методики обучения иноязычному общению / Е. И. Пассов. - М. : Русский язык, 1989. - 276 с. 3. Тарнопольский О. Б. Методика обучения английскому языку делового общения: [учеб. пособ.] / О. Б. Тарнопольский, С. П. Кожушко. - К. : Ленвит, 2004. - 191 с. 4. Шубин Э. П. Языковая коммуникация и обучение иностранным языкам / Э. П. Шубин. - M. : Просвещение, $1972 . \quad$ - 350 с. 5. Щукин А. Н. Лингводидактический энциклопедический словарь / А. Н. Щукин. - М. : Астрель: АСТ : Хранитель, 2007. - 746 с. 6. Common European Framework of Reference for Languages: learning, teaching, assessment. - Cambridge: Cambridge University Press, 2001. - 260 p.

УДК 378.14

А. О. Нікора,

кандидат пед. наук, доцент, Миколаївський національний університет імені В. О. Сухомлинського

\section{СУТНІСТЬ ТА ОСОБЛИВОСТІ МЕТОДИЧНОЇ ПІДГОТОВКИ МАЙБУТНЬОГО ВЧИТЕЛЯ ДО РОБОТИ В УМОВАХ ІННОВАЦІЙНИХ ПРОЦЕСІВ У ШКІЛЬНІЙ СУСПІЛЬСТВОЗНАВЧІЙ ОСВІТІ}

Нікора А.О. Сутність та особливості методичної підготовки майбутнього вчителя до роботи в умовах інноваційних процесів у шкільній суспільствознавчій освіті.

Стаття присвячена визначенню сутності та розкриттю особливостей методичної підготовки майбутнього вчителя до роботи в умовах інноваційних процесів у шкільній суспільствознавчій освіті.

Ключові слова: методична підготовка вчителя, інноваційний процес, суспільствознавча освіта.

Никора А.А. Сущность и особенности методической подготовки будущего учителя к работе в условиях инновационных процессов в школьном обществоведческом образовании.

Статья посвящена определению сущности и раскрытию особенностей методической подготовки будущего учителя к работе в условиях инновационных процессов в школьном обществоведческом образовании.

Ключевые слова: методическая подготовка учителя, инновационный процесс, обществоведческое образование.

Nikora A. Nature and features methodically preparing future teachers to work in innovative processes in school social science education.

Article is devoted to the definition of the nature and characteristics of the disclosure of methodological training future teachers to work in terms of innovation processes in the school social science education.

Key words: methodical teacher training, innovative process, social science education.

Для ефективного управління складним процесом освіти, що знаходиться в постійній динаміці розвитку, великого значення набуває чинник уміння вчителем передбачати основні тенденції та напрямки наступних змін. В умовах модернізації шкільної суспільствознавчої освіти вчителю не тільки важливо, але й необхідно володіти компетенціями, що дозволяють виявити інноваційну гнучкість.

Питання модернізації суспільствознавчої освіти відображено у працях К. Баханова, А. Булди, О. Пометун, Ф. Турченка, О. Турянської, О. Удода та багатьох інших. Зміни в завданнях, змісті та організації суспільствознавчої галузі досліджувалися науковцями Т. Ладиченко, О. Пометун та ін. Вимоги підготовки якісно нової генерації вчителів, які уміють і готові працювати в умовах швидкоплинних змін відображено у працях О. Глузмана, Л. Нечипоренко, В. Сагарди. Вивченням проблеми підготовки майбутніх учителів (зокрема - методичної) опікуються В. Гриньова, М. Коган, О. Рудницька, А. Старєва та інші. Однак, обгрунтування сутності та особливостей методичної підготовки майбутнього вчителя під кутом його готовності до роботи в умовах інноваційних процесів у 